グリオーマに対する化学療法

一最新のエビデンスを中心に一

佐々木 光1)

1）慶應義塾大学医学部脳神経外科

\title{
Recent Advance and Updates in Chemotherapy for Glioma
}

\author{
Hikaru Sasaki, M.D. ${ }^{1)}$ \\ 1) Department of Neurosurgery, Keio University School of Medicine
}

The approval of BCNU wafers and bevacizumab (BEV) has widened the therapeutic options for malignant glioma patients. Although these new drugs contribute to improve disease management in patients, there are some pitfalls associated with the use of these new drugs. On the other hand, the recent reports of the results of the randomized trials on anaplastic oligodendroglioma (AO) and elderly glioblastoma (GB) have significant impact on clinical practice. In this review, we discuss the risks and benefits of the two new drugs, as well as the updated standard treatment for $\mathrm{AO}$ and elderly GB.

Local chemotherapy with BCNU wafers offered a survival benefit to patients with recurrent as well as newly diagnosed malignant gliomas. BEV monotherapy was associated with a decrease in tumor volume as defined by contrast enhancement in the majority of the recurrent glioblastomas. The addition of BEV to radiotherapy (RT)/ temozolomide (TMZ) for newly diagnosed glioblastoma patients improved progression-free survival (PFS) but not overall survival (OS). The analyses of two phase III clinical trials from the 1990's with long-term follow-up have shown that early administration of chemotherapy improved the OS of patients with anaplastic oligodendroglial tumors harboring a 1p19q co-deletion. Moreover, two phase III clinical trials with elderly glioblastoma patients have shown that MGMT promoter methylation predicts increased OS for patients treated with TMZ monotherapy.

The recent approval of new drugs are encouraging. However, to fully benefit from these drugs, neurooncologists should correctly understand the results of the relevant clinical trials and be well aware of the possible risks. Current evidence suggests that molecular studies should be included in routine diagnostic procedures.

(Received March 7, 2014; accepted April 8, 2014)

Key words : chemotherapy, BCNU wafer, bevacizumab, anaplastic oligodendroglioma, elderly glioblastoma Jpn J Neurosurg（Tokyo）23: 547-558, 2014

\section{はじめに}

この 1〜2 年で, $\mathrm{BCNU}$ 徐放剤, ベバシズマブ, 5-ア ミノレブリン酸，タラポルフィンナトリウムなど，グリ オーマを対象疾患とする薬剤が次々と認可された。長い 間，放射線，ニトロソウレア剂，PAV 療法〔プロカルバ
ジン，ニムスチン $(\mathrm{ACNU})$, ビンクリスチン]，テモゾ ロミドで対応してきた中，治療手段が増え，患者，医療 従事者にとって朗報である。しかし，これらの新規薬剤 は従来の抗癌剤とは異なる特徴を有するため, 注意点や 副作用の可能性についての十分な知識が必要である。ま た，対象となる腫瘍型，病期（初発，再発)，治療効果の 
程度についても十分に理解して使用することにより, 初 めて患者に益することができる。一方, 大規模な臨床試 験の結果も続々と報告され, 日常臨床あるいは標準治療 にまで大きな影響を与えるものも少なくない. 本稿では, グリオーマに対する新規化学療法剤 2 剤 (BCNU 徐放 剤, ベバシズマブ）と, 分子マーカーの重要性が確認さ れた 2 つのトピックス (anaplastic oligodendroglioma, elderly glioblastoma）について概説する。臨床試駼結果の review を中心に記載し, 稿末に take home message とし て, 特に記憶に留めておきたいことをまとめた。薬物動 態や有害事象の頻度等詳細に関しては薬剂添付文書ある いは他著を参照されたい。

\section{BCNU wafer（ギリアデル）}

生体分解性のポリマーに BCNU（carmustine）を浸み 込ませた徐放性製剂であり, 腫瘍摘出後の切除面に留置 する。

再発 malignant glioma 222 例〔うち 145 例が glioblastoma（GB)]を対象とする, 二重盲検, ランダム化，プ ラセボ対照試験3)において, intention-to-treat (ITT) 解 析で生存期間に有意差は認めなかった〔中央值：プラセ ボ (=BCNU を浸み込ませていないポリマー) 留置群 23 weeks（w）vs BCNU wafer 留置群 $31 \mathrm{w}$, HR $0.83,95 \%$ CI $0.63 \sim 1.10, \mathrm{p}=0.19$ ] が, 腫瘍摘出率, KPS, 年齢な どの予後因子を調整した多変量解析では, BCNU wafer 留置により死亡リスクが減少した（HR 0.67，95\%CI $0.51 \sim 0.90, \mathrm{p}=0.006)$. GB の患者に限机ば, ITT 解析で は有意差を認めなかった（HR 0.81, p=0.22）が，多変 量解析では BCNU wafer 留置により統計学的に有意に 死亡リスクが減少した (HR 0.67, 95\%CI 0.48〜 0.95, p= $0.02)$.

初発腫瘍に対しては, 1997〜1999 年に登録された 240 例の malignant glioma（18〜65 歳, 単発テント上, KPS $>60 ， 240$ 例中 207 例は GB）を対象としたランダム化 比較試験 ${ }^{27)}{ }^{28)}$ (T-301 試験. Maximal resection+プラセ ボ wafer+放射線治療 vs maximal resection $+\mathrm{BCNU}$ wafer+放射線治療）において, BCNU wafer 群で統計学 的に有意に生存期間 (overall survival：OS）が延長され た〔ITT 解析 OS 中央值：プラセボ群 11.6 months（m) vs BCNU 群 $13.8 \mathrm{~m}, \mathrm{HR} 0.73,95 \% \mathrm{CI} 0.56 \sim 0.95, \mathrm{p}=$ 0.018]。予後因子を含めた多変量解析でも, BCNU wafer 留置による死亡リスクの減少が示された（HR 0.75, p= 0.045). GB の患者に限つた場合, 同様の傾向は認めたも のの, ITT 解析 (HR 0.78, 95\% CI 0.60 1.03, p =0.08)
でも多変量解析（HR 0.78，95\% CI 0.58 1.05, p=0.10） でも有意差には達しなかった。摘出率による subgroup 解 析 ${ }^{19)}$ では, complete resection（MRI で 90\%以上の摘出） 例では, ITT 解析で BCNU wafer 留置により有意な OS の延長を認めた（HR 0.58, 95\%CI 0.39〜0.86, $\mathrm{p}=0.01)$ が, partial resection (90\%未満) では有意差を認めなかっ た（HR 0.85，95\%CI 0.60 1.22, p=0.39）。 GB に限つ ても, complete resection 例では, BCNU wafer 留置によ る生存期間の延長を認めた (HR 0.62, 95\%CI 0.41〜 0.93, $\mathrm{p}=0.02)$.

放射線・テモゾロミド（TMZ）併用療法後に TMZ 内 服（day 1〜 5, 28-day cycle）を 6〜12 コース行う，いわ ゆる Stupp プロトコール（放射線/TMZ+TMZ）と， BCNU wafer 留置後に Stupp プロトコールを行う治療 （BCNU wafer+Stupp）との比較試験はなされていない. BCNU wafer+Stupp に関してはほとんどが retrospective な解析であるが，併用での OS 中央值はおおむね 17〜23 m であり ${ }^{11)}$, Stupp プロトコールにおける historical data (EORTC 26981/22981-NCIC CE3 $14.6 \mathrm{~m}$, RTOG0825 15.7 m, AVAglio 16.7 m) ${ }^{8) 10) 20)}$ と比べると, BCNU wafer による上乗せ効果がある可能性がある.

やはり retrospective な解析であるが, 65 歳以上の高齢 者 GB に対する BCNU wafer 留置による OS 延長効果も 報告されている7).

BCNU wafer は異物であり, 留置に関係する有害事象 としては, 異物に対する反応と感染に特に注意を要する. 痤攣発作, 脳浮腫, 摘出腔囊胞形成, 創傷治癒不良, 髄 液漏, 創傷感染, 髄膜炎などが報告されている ${ }^{15}$ (ギリア デル総合製品情報)。サル脳におけるデータで薬剤浸透範 囲が約 $6 \mathrm{~mm}$ であったこと, 初発腫瘍において partial resection 例では有意差が認められなかったこと年, さら に留置による浮腫増悪の可能性を考えれば, リスクと効 果の両面から, 切除不十分例に mass effect が解消されて いない状況で留置することは原則として避けるべきであ $ろ^{11)}$.

\section{Bevacizumab（アバスチン）}

ベバシズマブ (BEV) は, vascular endotherial growth factor（VEGF）A に対するヒト化モノクローナル抗体で あり, 分子標的薬である. 本邦では, BEV の薬事承認は 諸外国に遅れたが, この度世界で初めて, 初発悪性神経 膠腫に対する $\mathrm{BEV}$ 使用が認められた。

Friedman $ら^{9)}$ は, 放射線, TMZ 後の再発 GB 167 例を 対象として BEV 単独治療 $(10 \mathrm{mg} / \mathrm{kg}, 2$ 週ごと) あるい 


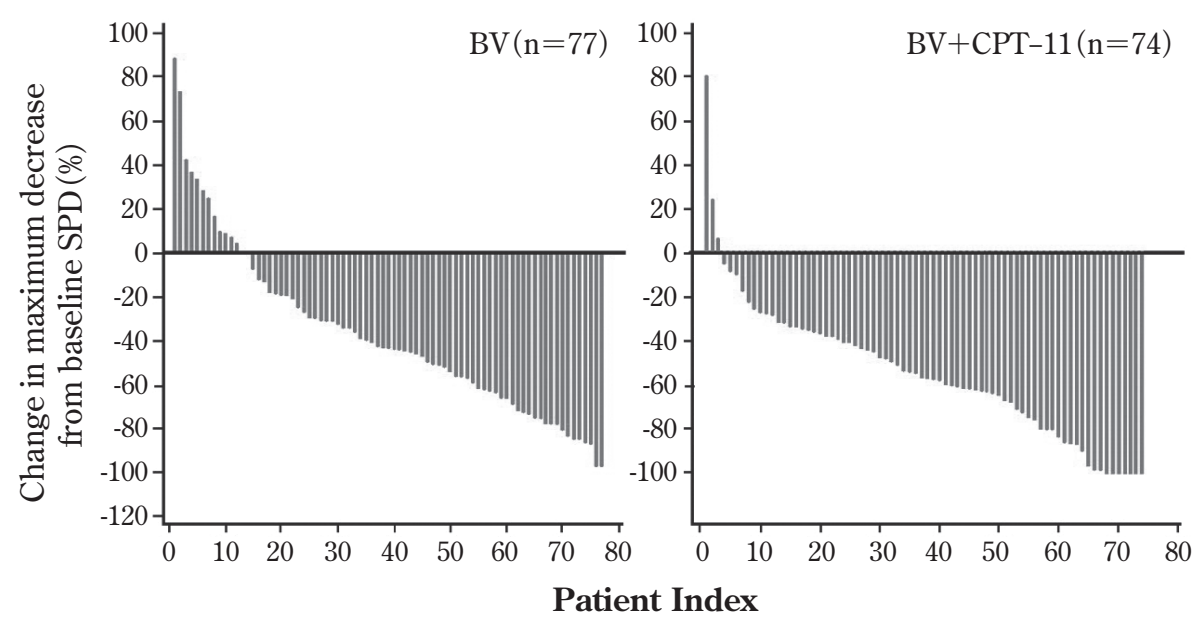

Fig. 1 Maximum decrease of tumor volume from baseline estimated by the sum of the products of tumor diameters (SPD)

The vertical axis indicates the percent change from baseline relative to the minimum SPD after the beginning of treatment. The horizontal axis indicates each patient. A negative value in the vertical axis indicates decrease in tumor volume relative to the baseline. Note that more than $80 \%$ of the patients in each treatment arm showed a decrease in tumor volume. (From Ref. 9. Reprinted with permission. (C)2010 American Society of Clinical Oncology. All rights reserved.)

$\mathrm{BV}$ : bevacizumab, CPT-11: irinotecan

は BEV/irinotecan（CPT-11）併用療法によるランダム 化第 2 相試験（non-comparative）を行った. BEV 単独 治療群における 6 力月無増悪生存率〔6m-PFS (progression-free survival) ]は 42.6\% $(97.5 \% \mathrm{CI} 29.6 \sim 55.5 \%)$ であり, historical control の $15 \%$ よも有意に良好とみ なされた（13\%以上の改善， $\mathrm{p}<0.0001)$. 奏効率〔partial response (PR) 以上]も, BEV 群 $28.2 \%$ (97.5\% CI 18.5〜 $40.3 \%), \mathrm{BEV} / \mathrm{CPT}-11$ 群 $37.8 \%$ (97.5\% CI 26.5〜 50.8\%) で, historical control（5\%）あるいは CPT-11 単独治療 $(10 \%)$ に比べ, 有意に上回ると判断された $(\mathrm{p}<0.0001)$. ここで奏効持続期間中央值（median response duration） は, BEV 群 $5.6 \mathrm{~m}, \mathrm{BV} / \mathrm{CPT}-11$ 群 $4.3 \mathrm{~m}$ であった. 重要 なことに，PR に至らない軽度の縮小まで含めれば，腫 瘍（造影領域）の縮小は $80 \%$ 以上の患者で認められた (Fig. 1)。無増悪生存期間（PFS）中央值は BEV 群 4.2 $\mathrm{m}, \mathrm{BV} / \mathrm{CPT}-11$ 群 $5.6 \mathrm{~m}$ であった。しかし, ランダム割 り付け後の生存期間中央值は, $\mathrm{BEV}$ 群 $9.2 \mathrm{~m}, \mathrm{BEV} / \mathrm{CPT}-$ 11 群 $8.7 \mathrm{~m}$ であり, historical control ${ }^{1)}$ と同等であった。一 方, 2013 年の第 49 回 American Society of Clinical Oncology（ASCO）年次総会（http://meetinglibrary.asco.org/) において, 放射線/TMZ 後の初回再発 GB に対して, $\mathrm{BEV} / \mathrm{CCNU}$ (lomustine) 併用療法が, BEV 単独あるい は CCNU 単独よりも有効であることが示唆された
(BELOB study. $9 \mathrm{~m}$ 生存率：BEV $38 \%$ vs CCNU $43 \%$ vs BEV/CCNU $59 \%)^{22)}$.

先ごろ論文化された初発 GB に対する 2 つの大規模 ランダム化第 3 相比較試験の結果が, 同 ASCO 年次総会 において報告された. Roche 社による企業治験（AVAglio 試験 $)^{8)} と$ Radiation Therapy Oncology Group (RTOG) に よる医師主導臨床試験（RTOG0825）であり, プロトコー ルに若干の相違はあるものの，いずれにおいても，標準 治療：放射線/TMZ/プラセボ併用療法 $+\mathrm{TMZ}$ (+プラセ ボ）と試験治療：放射線/TMZ/BEV 併用療法 $+\mathrm{TMZ} /$ BEV が比較された。 AVAglio 試験（921 例）では, PFS 中央值で標準治療群 $6.2 \mathrm{~m}$, 試験治療群 $10.6 \mathrm{~m}$ であり, BEV の併用により有意な延長が認められた（Fig. 2A, HR 0.64, 95\%CI 0.55 0.74, p<0.001). さらに, 試験 治療群では, 標準治療群に比し, KPS 70 以上が維持され た期間やステロイド開始までの期間が延長され，また健 康関連 QOL が維持・改善する傾向が示された。しかし OS では両治療群において有意差は認められなかった

（Fig. 2B， 中央值：標準治療 $16.7 \mathrm{~m}$ vs 試験治療 $16.8 \mathrm{~m}$, HR $0.88,95 \%$ CI $0.76 \sim 1.02, p=0.1)$. RTOG0825 試験 ${ }^{10)}$ （637 例）でも，OS は両治療群で同等であり（標準治療 $16.1 \mathrm{~m}$ vs 試験治療 $15.7 \mathrm{~m}$, HR 1.13, 95\%CI 0.93 1.37, $\mathrm{p}=0.21$ ), PFS は試験治療群で延長された（標準治療 7.3 


\section{A Progression-free survival}

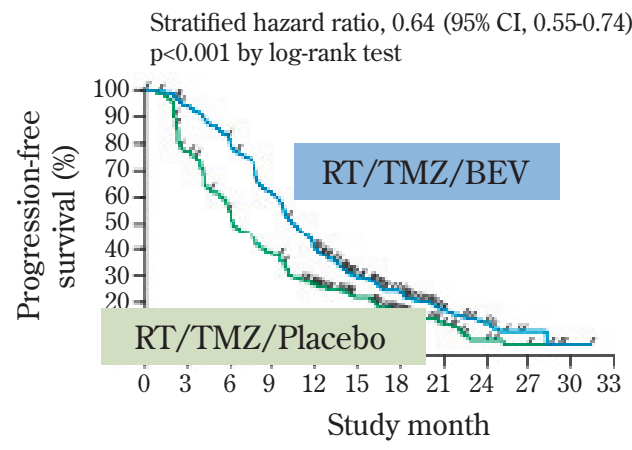

No. at risk

Placebo+RT-TMZ $4633492471701107747 \quad 23 \quad 8 \quad 4 \quad 000$

Bevacizumab+RT-TMZ $45842436627818910471 \quad 25 \quad 13 \quad 2 \quad 110$

\section{B Overall survival}

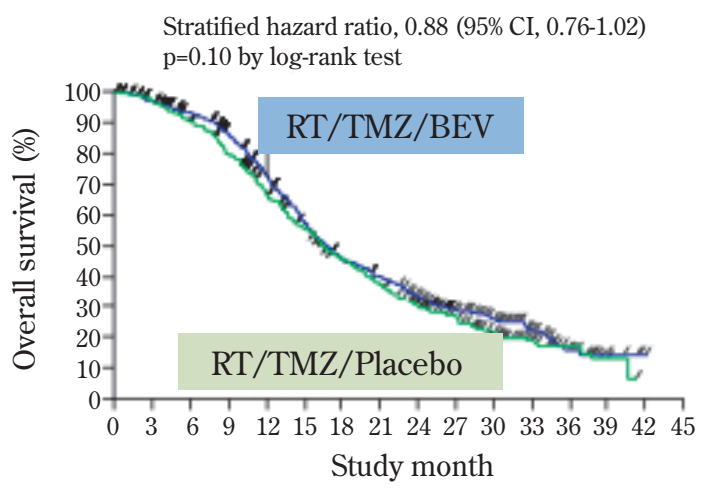

No. at risk

Placebo+RT- $46344440535529324520116311884532815 \quad 6 \quad 0 \quad 0$ TMZ

Bevacizumab+ $45844042138732225320317613991612711 \quad 4 \quad 1 \quad 0$ RT-TMZ

\author{
RT/TMZ/Placebo $6.2 \mathrm{~m}$ \\ vs RT/TMZ/BEV $10.6 \mathrm{~m}$ \\ HR 0.64, $\mathrm{p}<0.001$
}
RT/TMZ/Placebo $16.7 \mathrm{~m}$ vs RT/TMZ/BEV $16.8 \mathrm{~m}$
HR $0.88, p=0.10$

Fig. 2 AVAglio study

Kaplan-Meier analysis of progression-free survival (investigator-assessed PFS) (A) and overall survival (OS) (B) comparing the RT/TMZ/Placebo arm with the RT/TMZ/BEV arm. PFS was increased in the BEV arm compared to that in the placebo arm. However, OS did not differ significantly. (From Ref. 8. (C)2014 Massachusetts Medical Society. Reprinted with permission from Massachusetts Medical Society.)

$\mathrm{RT}$ : radiotherapy, $\mathrm{TMZ}$ : temozolomide, $\mathrm{BEV}$ : bevacizumab

$m$ vs 試験治療 10.7 m, HR 0.79, 95\% CI 0.66 0.94, p= 0.007）があらかじめ設定された有意水準（p<0.004）は 満たさなかった（Fig. 3)，比較的良好な予後が推測され る患者群〔O6-methylguanine DNA methyltransferase (MGMT) メチル化あり\&予後良好を示唆する遺伝子プロ ファイル〕では，試験治療群で OS が短縮される傾向が 示された $(25 \mathrm{~m}$ vs $16.7 \mathrm{~m}, \mathrm{HR} 2.27, \mathrm{p}=0.07)$. 認知機 能や症状の苦痛度においては, 治療開始 5 力月後ころよ り，試験治療群で標準治療群よりも悪化する傾向が示さ れた（RTOG0825. 注：AVAglio 試験では逆の結果が示さ れている)。一方やはり同年の ASCO 年次総会（http:// meetinglibrary.asco.org/）において, MGMT 非メチル化の 初発 GB に対しては，放射線/ $\mathrm{BEV}+\mathrm{BEV} / \mathrm{CPT}-11$ が放 射線 $/ T M Z+T M Z$ に比し， 6 m-PFS において有意に良 好であったと報告されている（GLARIUS trial。標準治療 $26.2 \%$ vs 試験治療 $\left.71.1 \%, \mathrm{p}<0.0001)^{12}\right)$ (OS では差な し, $\mathrm{HR}=1.02, \mathrm{p}=0.90,2014 \mathrm{ASCO}$ 年次総会).

$\mathrm{BEV}$ に関連する有害事象としては, 出血, 血栓塞栓症 (心筋梗塞，脳梗塞，深部静脈血栓症，肺塞栓症)，創傷 治癒不全，血栓性微小血管症，好中球減少，高血圧，消

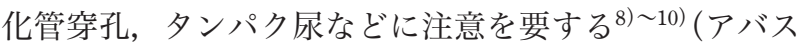
チン医薬品インタビューフォーム).
BEV の使用にあたつては，これらの特有の有害事象の 可能性のほか, 疑似奏効 (pseudoresponse : 真の抗腫瘍効 果を伴わない画像所見の改善）という現象に注意を要す る（Fig. 4)。脳腫瘍の治療における response 評価におい ては, 従来，主として，造影領域を標的とし，そこにス テロイドの使用量と神経学的所見の変化を考慮した Macdonald 基準 ${ }^{16)}$ が使用されてきた。しかし，腫瘍の造 影効果は元来主に血液脳関門 (blood brain barrier：BBB) の障害を反映するものであり，近年，BEV など血管透過 性を修飾する薬剤による，腫瘍の活動性とは直接関係の ない造影効果の変化が問題とされるようになった ${ }^{2)}$.こ のような現象に対応するため, 最近新たな response 評価 基準が提唱された〔response assessment in neuro-oncology（RANO）基準 ${ }^{26)}$. RANO 基準では，抗血管新生療 法を受けている患者においては MRI における非造影領 域（T2/FLAIR 高信号域）の明らかな拡大があれば progression と判断される. BEV 使用時には, 治療による真 の抗腫瘍効果の判定困難, progression 診断困難などに留 意する必要がある。

$\mathrm{BEV}$ 併用により OS が延長しないこと, 有害事象の可 能性, 予後良好群における負の効果の可能性 （RTOG0825）などを考慮すれば，初発 GBに対する現時 


\section{A Progression-free survival}

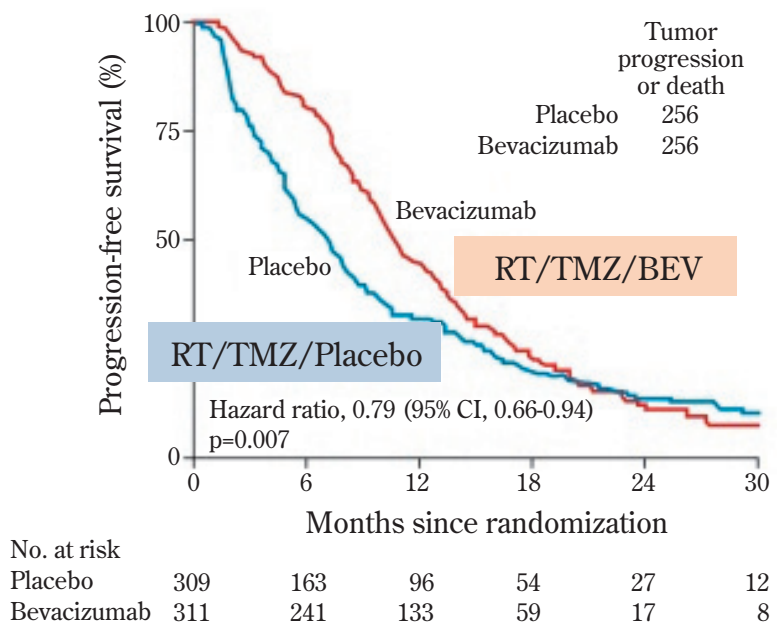

RT/TMZ/Placebo $7.3 \mathrm{~m}$ vs RT/TMZ/BEV $10.7 \mathrm{~m}$

HR $0.79, \mathrm{p}=0.007$

\section{B Overall survival}

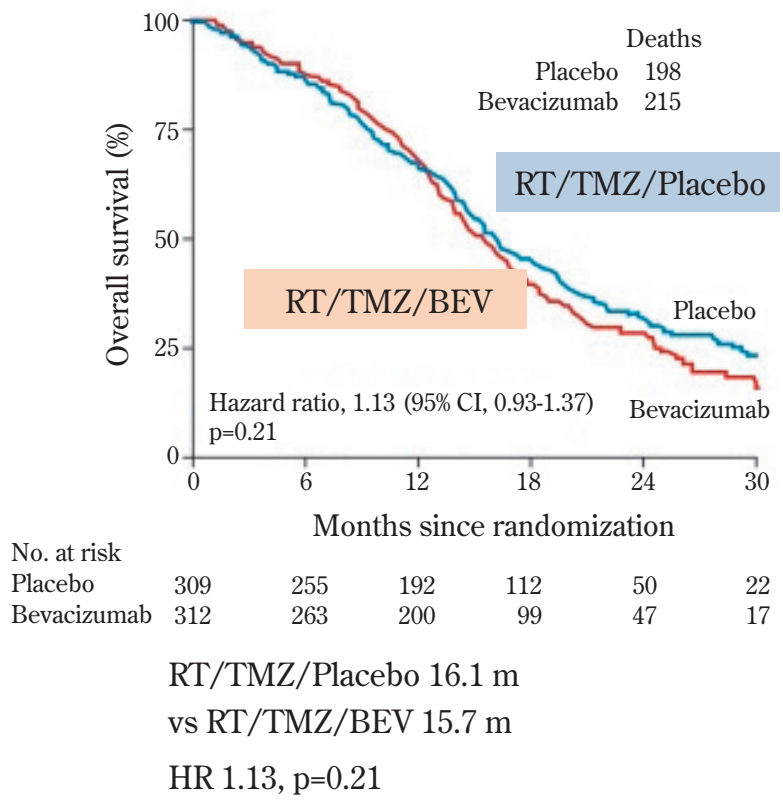

Fig. 3 RTOG0825 study

Kaplan-Meier analysis of progression-free survival (PFS) (A) and overall survival (OS) (B) comparing the RT/TMZ/Placebo arm with the RT/TMZ/BEV arm. PFS was prolonged in the BEV arm but did not reach the pre-specified target. OS was similar in the BEV arm and placebo arms. (From Ref. 10. (C)2014 Massachusetts Medical Society. Reprinted with permission from Massachusetts Medical Society.)

$\mathrm{RT}$ : radiotherapy, $\mathrm{TMZ}$ : temozolomide, $\mathrm{BEV}$ : bevacizumab

点での標準治療は Stupp プロトコールである。しかし， 症候性の残存腫瘍が認められる場合，高齢者など QOL の改善が目的とされる場合，あるいは MGMT 非メチル 化腫瘍などに対して, 患者と相談のうえ問題点を認識し つつ併用することは考慮されてもよいと考える。

\section{Anaplastic oligodendroglioma}

昨年, 2006 年に報告された 2 つの第 3 相ランダム化 比較試験の, 長期の経過観察後の新たな解析結果が報告 された。結果が一部覆され，標準治療が変更された。

RTOG $と$ European Organisation for Research and Treatment of Cancer (EORTC) による, 初発の成人 anaplastic oligodendroglioma/oligoastrocytoma を対象とす る別個の臨床試験である ${ }^{4) 23)}$. プロトコールは類似して おり，RTOG9402では，放射線治療単独（標準治療）vs intensive PCV 〔lomustine (CCNU) $130 \mathrm{mg} / \mathrm{m}^{2}$, day 1 , procarbazine $75 \mathrm{mg} / \mathrm{m}^{2}$, day $8 \sim 21$, vincristine $1.4 \mathrm{mg} / \mathrm{m}^{2}$, day 8 and 29） 4 コース+放射線治療で比較し, 一方 EORTC26951 では，放射線治療単独（標準治療）vs 放射 線治療 + PCV 〔lomustine $110 \mathrm{mg} / \mathrm{m}^{2}$, day 1 , procarbazine
$60 \mathrm{mg} / \mathrm{m}^{2}$, day $8 \sim 21$, vincristine $1.4 \mathrm{mg} / \mathrm{m}^{2}$, day 8 and 29 (max. $2 \mathrm{mg} /$ body) ], 6 コースで比較検討を行った。 2006 年の第一報〔median follow-up：RTOG9402 5.1 years（y), EORTC $269515.0 \mathrm{y}$ 〕では，両試験ともに， 全体の解析で，試験治療群で PFS の延長を認めたが OS に差はなかった．特に $1 \mathrm{p} 19 \mathrm{q}$ codeletion（共欠失）のある 腫瘍では，試験治療群（つまり PCV の上乗せにより） で PFS が延長する傾向が示された（Fig. 5A）。1p19q 共 欠失のある腫瘍は治療法にかかわらず共欠失のない腫瘍 に比べ OS が良好であったが，治療法による OS の差は 認めなかった (Fig. 5B). 1p19q 共欠失のある腫煬におい て, PFS で認められた PCV の上乗せ効果が OS で消失し た理由として, 標準治療群における再発時 PCV 療法に よる salvage のため, と解釈されていた。すなわち, 2006 年時点での結論は, $1 \mathrm{p} 19 \mathrm{q}$ 共欠失のある gradeIII oligo 系 腫瘍においては，共欠失のない腫瘍に比へ，治療法にか かわらず OS も PFS も良好である，しかし PCV 療法の タイミング（初回か再発時か）は OS に影響しない, で あり, $1 \mathrm{p} 19 \mathrm{q}$ 共欠失の有無は, prognostic factor（治療法 にかかわらず予後に影響する因子）と考えられた。また， 放射線単独と $\mathrm{PCV}+$ 放射線で OS に有意差を認めな 


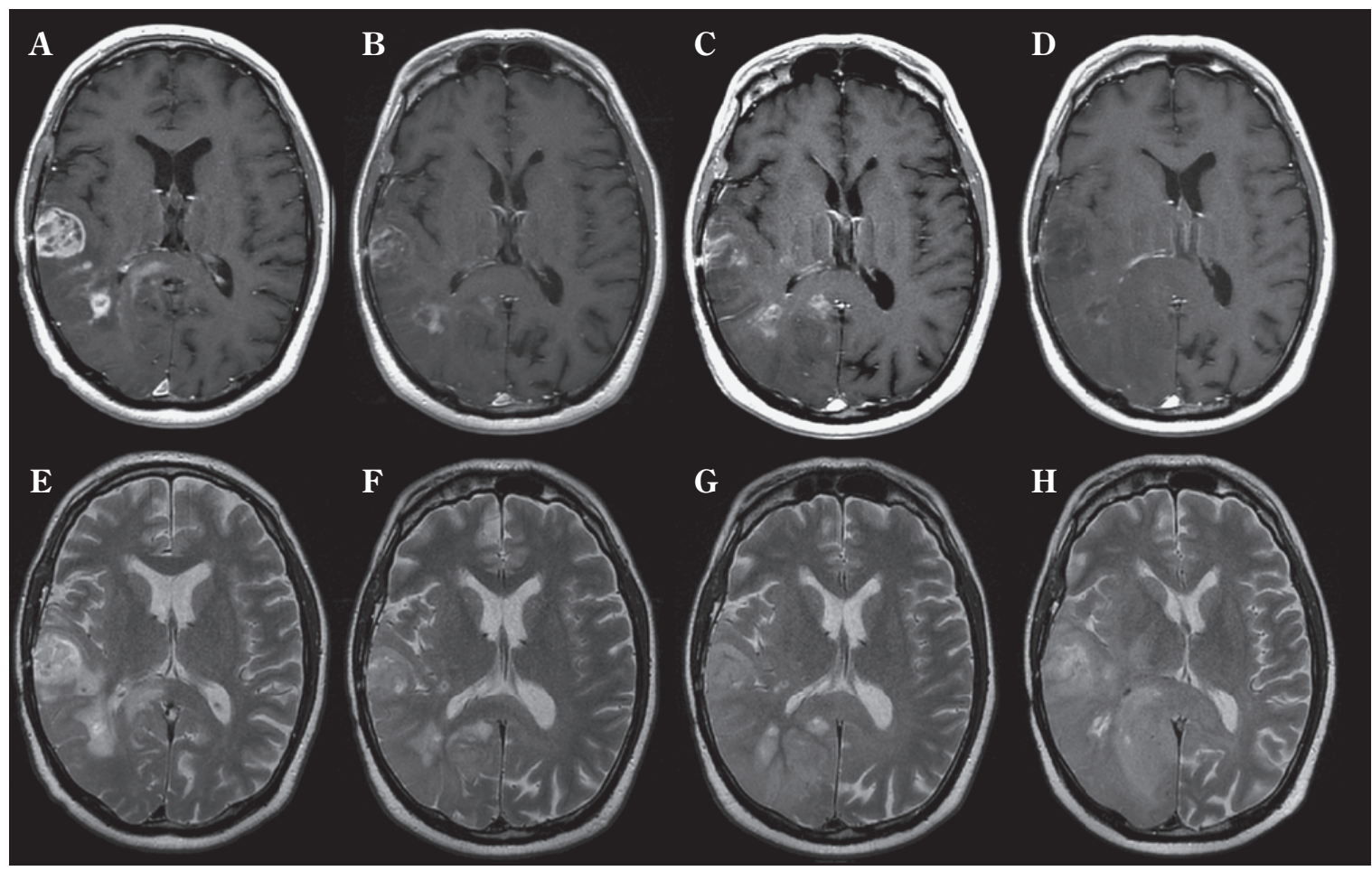

Baseline

After 6 weeks

After 12 weeks

After 18 weeks

Fig. 4 Pseudoresponse

Serial MRI of a patient with glioblastoma treated with an angiogenesis inhibitor.

Upper panels : T1-weighted images after contrast administration.

Lower panels: T2-weighted images.

Despite a clear decrease of contrast enhancement, there is a continuous increase of the abnormal highintensity area on T2-weighted images indicating diffuse infiltration. (From Ref. 2. (C)2014 Wolters Kluwer Health. Reprinted with permission from Wolters Kluwer Health.)

かったこと，さらに，PCV 療法の毒性などを考慮し て, この時点での gradeIII oligo 系腫瘍に対する標準治療 は，共欠失の有無にかかわらず，放射線治療単独であっ た.

RTOG9402（291 例）の長期追跡結果（median followup : $11.3 \mathrm{y})^{5)}$ では, 全体の解析結果は 2006 年と同様で, PFS で有意差を認めた（放射線単独 $1.7 \mathrm{y}$ vs PCV+放射 線 $2.6 \mathrm{y}, \mathrm{HR} 0.68, \mathrm{p}=0.003)$ が，OS に有意差を認めな かった（放射線単独 $4.7 \mathrm{y}$ vs PCV+放射線 $4.6 \mathrm{y}, \mathrm{HR}$ $0.79,95 \% \mathrm{CI} 0.60 \sim 1.04, \mathrm{p}=0.1) .1 \mathrm{p} 19 \mathrm{q}$ 共欠失は $48 \%$ (FISH， 126 of 263 informative cases) の症例で認められ た. 2006 年同様, 共欠失のある腫瘍では, 治療法にかか わらず, 共欠失のない腫瘍よりも OS が延長していた(放 射線単独 codel $7.3 \mathrm{y}$ vs non-codel $2.7 \mathrm{y}$, HR $0.40,95 \%$ CI $0.27 \sim 0.60, \quad \mathrm{p}<0.001 ; \mathrm{PCV}+$ 放射線 codel $14.7 \mathrm{y}$ vs non-codel 2.6 y, HR 0.36, 95\% CI 0.23 0.57, $\mathrm{p}<0.001$ ). 2006 年と異なり, 共欠失のある腫瘍では治療法による
OS の差が認められ，初期治療に PCV を入れることによ り PFS だけでなくOS も延長した (Fig. 6B, codel PFS： 放射線単独 $2.9 \mathrm{y}$ vs PCV+放射線 $8.4 \mathrm{y}, \mathrm{HR} 0.47,95 \% \mathrm{CI}$ $0.30 \sim 0.72, \mathrm{p}<0.001$; OS : 放射線単独 $7.3 \mathrm{y}$ vs PCV+放 射線 $14.7 \mathrm{y}, \quad \mathrm{HR} 0.59,95 \% \mathrm{CI} 0.37 \sim 0.95, \mathrm{p}=0.03)$. 共 欠失のない腫瘍の患者では, 両治療群で PFS も OS も差 がなかった（Fig. 6A, non-codel PFS: 放射線単独 $1.0 \mathrm{y}$ vs PCV+放射線 $1.2 \mathrm{y}, \mathrm{HR} 0.81,95 \% \mathrm{CI} 0.56 \sim 1.16, \mathrm{p}=$ 0.24 ; OS : 放射線単独 $2.7 \mathrm{y}$ vs PCV+放射線 $2.6 \mathrm{y}, \mathrm{HR}$ $0.85,95 \% \mathrm{CI} 0.58 \sim 1.23, \mathrm{p}=0.39)$. 放射線単独群の多く においては, 再発時に化学療法が施行されていた（salvage chemotherapy: 放射線単独 $79 \%$ vs PCV+放射線 $43 \%)$. 最近, 非共欠失でも isocitrate dehydrogenase (IDH) 遺伝子の変異ありの腫瘍は PCV 追加により OS が延長されたことが報告された ${ }^{6)}$.

EORTC26951 (368 例, median follow-up : $11.7 \mathrm{y})^{24)}$ で は, 全体の ITT 解析で, 試験治療群で PFS も OS も有 


\section{A Progression-free survival}

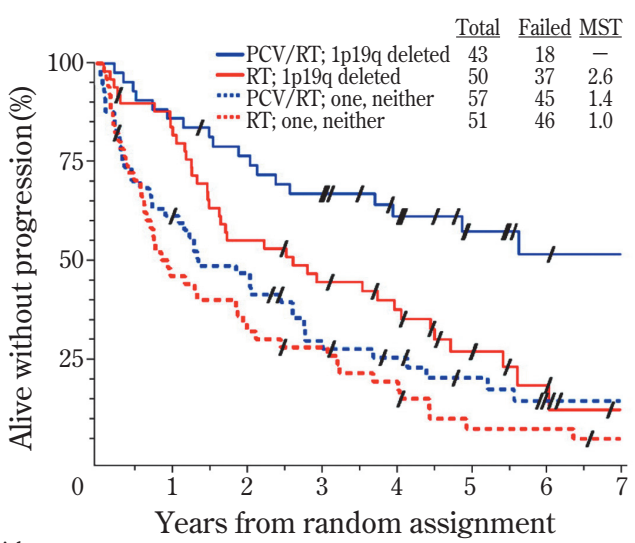

$\begin{array}{llllrl}\text { Patients at risk: } & & & & & \\ \text { 二 } & 43 & 37 & 32 & 9 & 8 \\ \ldots . . & 50 & 41 & 27 & 7 & 1 \\ \ldots & 57 & 35 & 26 & 3 & 1\end{array}$

Codeleted :

RT 2.6 y vs PCV + RT not reached

HR $0.42, p=0.001$

Non-codeleted : RT 1 y vs PCV + RT 1.4 y

HR $0.78, p=0.12$

\section{B Overall survival}

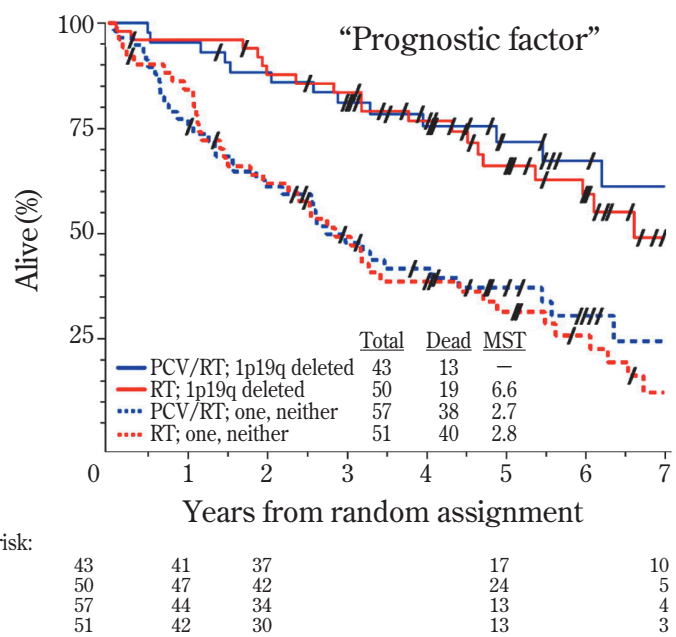

Codeleted :

RT 6.6 y vs PCV + RT not reached

HR $0.81, \mathrm{p}=0.28$

Non-codeleted : RT 2.8 y PCV + RT 2.7 y

HR 0.91, $\mathrm{p}=0.33$

Fig. 5 Kaplan-Meier analysis separated by treatment and genotype indicated in the initial report (median follow-up 5.1 years)

A : Progression-free survival (PFS). In patients with 1p19q codeleted tumors, the addition of PCV was significantly associated with longer PFS. In contrast, patients with non-codeleted tumors showed no significant difference between the two treatment arms.

B : Overall survival $(\mathrm{OS})$. OS was significantly increased in patients with co-deleted tumors compared to that in patients with non-codeleted regardless of treatment. (From Ref. 4. Reprinted with permission. (C)2010 American Society of Clinical Oncology. All rights reserved.)

$\mathrm{PCV}$ : procarbazine, lomustine, and vincristine, RT : radiotherapy, MST : median survival time

\section{Overall survival}

A Non-codeleted

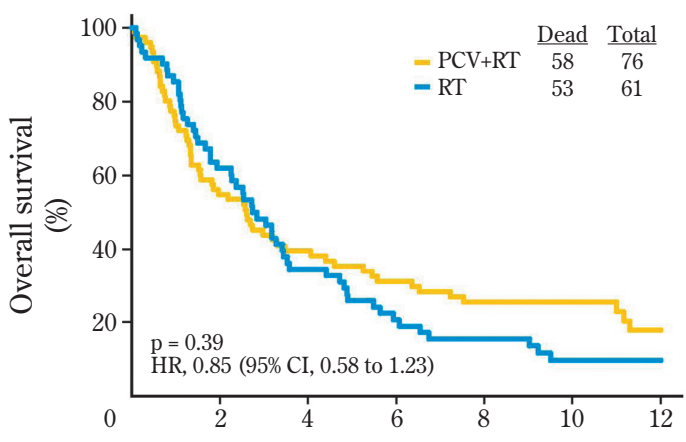

No. at risk $\mathrm{PCV}+\mathrm{RT}$

RT

Time since random assignment (years)

$$
\begin{aligned}
& \text { RT } 2.7 \text { y vs PCV plus RT } 2.6 \text { y } \\
& \text { HR } 0.85, p=0.39
\end{aligned}
$$

\section{B codeleted}

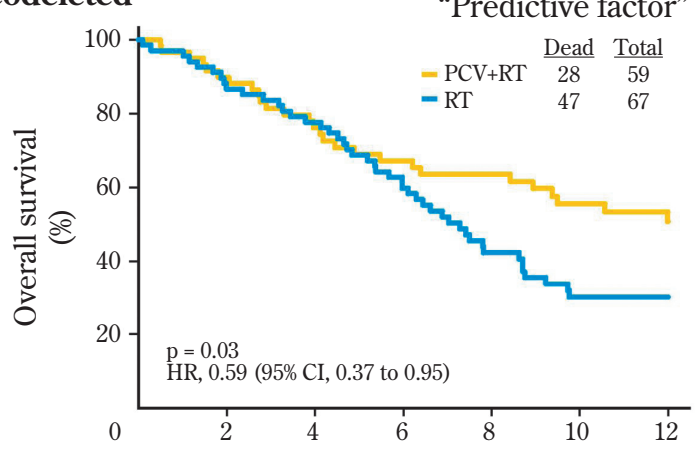

No. at risk $\mathrm{PCV}+\mathrm{RT}$ $\mathrm{RT}$

Time since random assignment (years)

$\begin{array}{lllllll}59 & 53 & 43 & 37 & 32 & 27 & 18 \\ 67 & 58 & 52 & 40 & 26 & 15 & 13\end{array}$

RT 7.3 y vs PCV plus RT 14.7 y

HR $0.59, \mathrm{p}=0.03$

Fig. 6 Kaplan-Meier analysis of overall survival after long-term follow-up (median 11.3 years) of patients with anaplastic oligodendroglioma/oligoastrocytoma and 1p/19q codeleted (B) or non-codeleted (A). Note that the survival curves in patients with the codeletion begin to diverge after 5 years of followup. (From Ref. 5. Reprinted with permission. (C)2010 American Society of Clinical Oncology. All rights reserved.) 


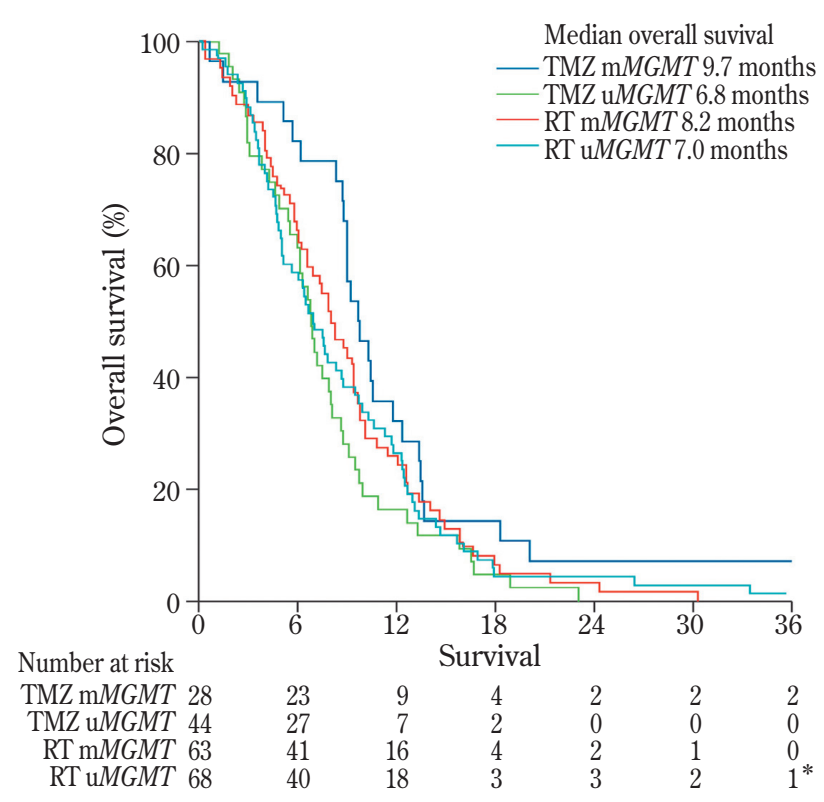

Fig. 7 Kaplan-Meier analysis of overall survival

Comparison of four subgroups: methylated MGMT treated with temozolomide, unmethylated MGMT treated with temozolomide, methylated MGMT treated with radiotherapy, and unmethylated MGMT treated with radiotherapy. Of patients treated with temozolomide, those with MGMTmethylated tumors had better survival than those with unmethylated tumors. By contrast, MGMT status did not affect the survival of patients treated with radiotherapy. (From Ref. 17. (C)2014, with permission from Elsevier.)

意な延長を認めた（PFS：放射線単独 $1.1 \mathrm{y}$ vs 放射線十 PCV 2 y, HR 0.66, 95\%CI 0.52 0.83, p=0.0003; OS : 放射線単独 $2.6 \mathrm{y}$ vs 放射線 + PCV $3.3 \mathrm{y}, \mathrm{HR} 0.75,95 \% \mathrm{CI}$ $0.60 \sim 0.95, \mathrm{p}=0.018) .1 \mathrm{p} 19 \mathrm{q}$ 共欠失は $25 \%$ の症例で認 められた。共欠失のある腫瘍では, 非共欠失に比べ, PCV 追加による死亡リスクの減少が大きかった (OS codel： 放射線単独 $9.3 \mathrm{y}$ vs 放射線 + PCV not reached, HR 0.56, $95 \%$ CI $0.31 \sim 1.03$; non-codel: 放射線単独 $1.8 \mathrm{y}$ vs 放射 線 +PCV 2.1 y, HR 0.83，95\%CI 0.62〜1.10). PFS にお いても，PCV 追加による延長効果は，共欠失のある腫瘍 において，より大きかった（codel：放射線 $4.2 \mathrm{y}$ vs 放射 線 + PCV $13.1 \mathrm{y}, \quad$ HR $0.42,95 \%$ CI $0.24 \sim 0.74$; noncodel : 放射線単独 0.8 y vs 放射線 + PCV 1.3 y, HR 0.73 , 95\%CI 0.56〜0.97). IDH1/2 変異と MGMT メチル化に ついても解析され, IDH 変異あるいは MGMTメチル化 ありで, PFS も OS も延長する傾向が示され, 多変量解 析では IDH 変異と $1 \mathrm{p} 19 \mathrm{q}$ 共欠失が独立した予後因子で
あった。

長期経過観察後の解析にて第一報の結果が一部覆つた が，2つの臨床試験の結果はほぼ同様であった。 $1 \mathrm{p} 19 \mathrm{q}$ 共欠失を持つ gradeIII oligo 系腫瘍に対しては, 初期治療 で化学療法を入れることがきわめて重要であり, 現時点 での標準治療は, 放射線 $+\mathrm{PCV}$ (あるいは $\mathrm{PCV}+$ 放射線) と考えてよ(5)2425)．PCV の代わりに TMZ を使用する ことに関しては議論があり, 副作用が少なく, すでに汎 用されており，しかも oligo 系以外のグリオーマにおい て PCVよりも有効とされてきた TMZ を使用するのは 妥当であるという意見がある一方 ${ }^{25}, 1 \mathrm{p} 19 \mathrm{q}$ 共欠失を持 つ oligo 系腫瘍における PCV の優位を示した報告もあ る ${ }^{14)}$. また, vincristine は $\mathrm{BBB}$ を通過しにくいので PC (procarbazine, CCNUのみ) でよいという意見 ${ }^{25}$, 最近 報告された TMZ と hypermutator phenotype の関連性 ${ }^{13)}$ に関する危惧もある。放射線 + PCV と Stupp プロトコー ルを比較する大規模臨床試験（NCCTG N0557/ RTOG1071/EORTC26081）の結果が待たれるが, 長期の 経過観察が必要であり, 結論が出るのは 10 年以上先に なるであろう。いずれにしても，2つの臨床試験の経緯 と結果から, グリオーマにおける分子生物学的分類と長 期 follow-up の重要性が確認された。

\section{Elderly glioblastoma}

放射線に TMZ を併用する Stupp プロトコールが，GB に対する標準治療であることが確立された EORTC と National Cancer Institute of Canada (NCIC) による臨床試 験では, 対象年齢は 18〜 70 歳であった。この臨床試験 では, 50 歳未満あるいは 50 60 歳の年龄層と比べると, 60 歳以上では TMZ の上乗せ効果は減少する傾向が示さ れ，特に 65 歳以上では恩恵が明らかでなかった（>60： 放射線単独 OS 中央值 $11.8 \mathrm{~m}$ vs 放射線/TMZ $10.9 \mathrm{~m}$, HR 0.7，95\%CI 0.5〜0.97) ${ }^{17) 21)}$ 。また，カナダでは， 60 歳以上の GB 患者を対象として, 放射線標準照射 (60 Gy/ 30 分割）と短期照射 (40 Gy/15 分割) を比較検討する 臨床試験が行われ ${ }^{18)}$, OS は同等であり（標準 $5.1 \mathrm{~m}$ vs 短期 $5.6 \mathrm{~m}$ ), ステロイド増量を必要とした患者の割合は 短期照射のほうが少なかった。このような背景の中で, 近年, 高齢者 GB を対象とする 2 つ第 3 相ランダム化 比較試験の結果が報告された。

ドイツの NOA-08 試験 29 は, 65 歳以上の初発 malignant astrocytoma (glioblastoma, anaplastic astrocytoma) を対象とする, dose-dense TMZ (ddTMZ：TMZ $100 \mathrm{mg} /$ $\mathrm{m}^{2}, 1$ week on 1 week off) の, 放射線治療 (60 Gy, 
$1.8 \sim 2.1 \mathrm{~Gy} / 1$ 分割）単独に対する非劣性試験である. 非 劣性の受容限界は, 放射線群の OS, event-free survival (EFS) からー25\%までとされた. 373 例 (anaplastic astrocytoma：40, glioblastoma：331) でITT 解析が行われた。 有害事象は ddTMZ 群でより高頻度でみられたが, 総じ て両治療ともよく耐用された。ddTMZ 群の治療回数中央 值は 5 コース (10 週) であった. OS, EFS ともに ddTMZ の非劣性が示された (OS 中央值: 放射線群 $9.6 \mathrm{~m}$ vs ddTMZ 群 $8.6 \mathrm{~m}$, HR 1.09, 95\%CI 0.84 1.42, p=0.033). MGMT のプロモーターメチル化の有無は 209 例で確認 され，73 例 $(35 \%)$ でメチル化が認められた. ddTMZ 群では, MGMTメチル化のある腫瘍で, メチル化のない 腫瘍に比べ EFS, OS ともに有意な延長が認められた (EFS: メチル $8.4 \mathrm{~m}$ vs 非メチル $3.3 \mathrm{~m}, \mathrm{p}<0.0001$; OS : メチル not reached vs 非メチル $7 \mathrm{~m}, \mathrm{p}=0.009)$ が, 放射 線群ではメチル化の有無は EFS, OS に影響しなかった (EFS：メチル $4.6 \mathrm{~m}$ vs 非メチル $4.6 \mathrm{~m}$; OS : メチル 9.6 $\mathrm{m}$ vs 非メチル $10.4 \mathrm{~m})$. QOL に関するスコアは, ddTMZ 群, RT 群で同様であった。 そのほか, 多変量解析にて, 摘出率 (complete resection vs incomplete resection vs biopsy）が OS に関係する独立した予後因子であること が確認された。

もう一つは, スウェーデン，ノルウェーなど北欧諸国 を中心に行わ机た， 60 歳以上の初発 GB を対象とする， 標準放射線治療単独 $(60 \mathrm{~Gy} / 30$ 分割 $)$ vs 短期放射線治 療単独 (34 Gy/10 分割) vs TMZ 単独 $\left(200 \mathrm{mg} / \mathrm{m}^{2}\right.$, day $1 \sim 5,28$-day cycle, 6 コース) の第 3 相ランダム化比較 試験である (Nordic Clinical Brain Tumour Study

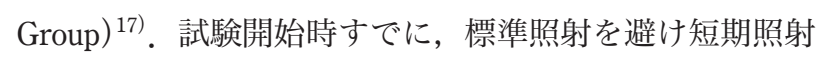
を行うのが一般的であったため, 一部の施設には, 短期 照射単独と TMZ 単独の 2 群への割り付けが許容され た. 342 例が登録され, うち 291 例は 3 群に割り付けら れ, 51 例は 2 群に割り付けられた。放射線治療をプロト

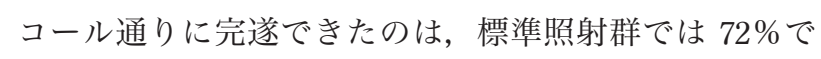

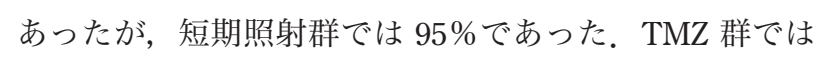
全 6 コースを終了したのは $34 \%$, 投与コース数中央値 は 4 コースであった。全体の解析では, TMZ 群は標準 照射群に比べ有意に OS が延長していたが (OS：標準照 射 $6.0 \mathrm{~m}$ vs TMZ $8.3 \mathrm{~m}, \mathrm{HR} 0.70,95 \% \mathrm{CI} 0.52 \sim 0.93, \mathrm{p}=$ 0.01 ), 短期照射群と標準照射群では有意差は認めなかっ た（短期照射 $7.5 \mathrm{~m}$, HR $0.85,95 \% \mathrm{CI} 0.64 \sim 1.12, \mathrm{p}=$ $0.24)$. 年齢別でみると, $60 \sim 70$ 歳では, 3 治療群の間に 有意差は認めなかった $(\mathrm{OS}$ : 標準照射 $7.6 \mathrm{~m}$ vs 短期照 射 $8.8 \mathrm{~m}$ vs TMZ $7.9 \mathrm{~m}$ ) が, 70 歳以上では, TMZ 群あ るいは短期照射群で, 標準照射群よりも OS が延長して
いた〔OS：標準照射 $5.2 \mathrm{~m}$ （HR 1.0）vs 短期照射 $7.0 \mathrm{~m}$ (HR 0.59, 95\%CI 0.37 0.93, p=0.02) vs TMZ $9.0 \mathrm{~m}$ (HR $0.35,95 \% \mathrm{CI} 0.21 \sim 0.56, \mathrm{p}<0.0001)]$. TMZ 群と短期照 射群の比較では, 全体でも年齢群別でも有意差を認めな かった. MGMT プロモーターメチル化は, 評価可能 203 例中 91 例 $(45 \%)$ で認められた. TMZ 治療群では, メ チル化のある腫瘍がない腫瘍に比べ, OS が有意に良好 であった（OS：TMZメチル $9.7 \mathrm{~m}$ vs TMZ 非メチル 6.8 m, HR 0.56, 95\% CI 0.34 0.93, p=0.02, Fig. 7). 放射 線治療群（標準照射十短期照射）では, メチル化の有無 による OS の差は認められなかった（OS：放射線メチル $8.2 \mathrm{~m}$ vs 放射線非メチル $7.0 \mathrm{~m}$, HR 0.97, p = 0.81, Fig. 7). EORTC QLQ-30 による QOL 評価では, 総じて TMZ 群のほうが RT 群よりも良好であった。

2 つの第 3 相臨床試験はほぼ一致した結果を示し, 高 齢者 GB に対して, TMZ 単独治療は放射線単独治療に劣 らないこと, 70 歳以上の GB に対しては, TMZ 単独治 療あるいは短期放射線照射が標準照射に優ること, 高齢 者 GB において, TMZ の効果は MGMT メチル化により 予測されること（predictive factor）が示された。70 歳以 上の高齢者 GB に対しては, 現時点の標準治療は, 短期 放射線照射 (40 Gy/15 分割や $34 \mathrm{~Gy} / 10$ 分割) と考える 専門家が多い.さらに MGMTメチル化の有無を考慮す るのが望ましく, 現時点で推奨される治療法は, 以下の ように考える。

$\langle 70$ 歳以上 $\mathrm{GB}\rangle$

MGMT メチル化あり $\rightarrow \mathrm{TMZ}$ 単独，または短期照射/ TMZ 併用療法

MGMT メチル化なし (または不明 $) \rightarrow$ 短期照射単独, ま たは短期照射/TMZ 併用療法

EORTC, NCIC による, 65 歳以上の GB を対象とする, 短期照射 vs 短期照射/TMZ の結果が待たれる (EORTC26062/NCIC-CE6).

\section{おわりに}

$\mathrm{BCNU}$ 徐放剂や $\mathrm{BEV}$ などの新規薬剤は, 骨髄抑制が 用量規定因子である従来の内服あるいは注射の抗癌剂と は異なる特徵を有し, 各薬剤の効果や関連有害事象を熟 知して使用することが重要である。一方, 特に BEV に 関しては, 本邦は世界で初めて初発腫瘍に対して認可さ れた国であり, 初発悪性神経膠腫に対する可能性を探求 することは，世界の中での役割とも考える.

また, anaplastic oligodendrogliomaにおける 1p19q 共 欠失, elderly glioblastoma における MGMT のように, 
腫瘍型によっては遺伝子診断に基づく個別化治療が必須 となりつつある。治療方針決定のためには遺伝子診断が 必要不可欠な状況となっていることを認識し，そのよう な体制の普及が急務である。

\section{TAKE HOME MESSAGES}

\section{BCNU wafer}

a ）再発および初発 malignant gliomaに対して, 摘出 後切除面に BCNU wafer を留置することにより生存期 間が延長した (ここで初発時の治療アームは, 放射線 vs BCNU wafer+放射線である).

b ) 特に $90 \%$ 以上の摘出が行われた症例群で BCNU wafer 留置による生存期間の延長が認められた（部分摘 出例では認められない).

c ） BCNU wafer 留置に関係する有害事象として，炎 症反応（および浮腫）と感染に注意する。薬剤浸達距離 と反応性浮腫の可能性などを考慮すると, 切除不十分例 に留置することは原則として避けるべきである.

\section{Bevacizumab}

a ）再発 GB の大部分が BEV 治療により縮小（造影 領域）し, BEV 単独治療による $6 \mathrm{~m}-\mathrm{PFS}$ は $42.6 \%$, 奏 効率 $(\mathrm{CR} / \mathrm{PR})$ は $28.2 \%$, response の持続期間は $5.6 \mathrm{~m}$, PFS 中央值は $4.2 \mathrm{~m}$ である.

b) 初発 GB に対し, Stupp プロトコールに BEV を併 用することで PFS は約 3〜4 力月延長される。しかし OS は延長されない（初発 GB に対する現時点での標準 治療は放射線/TMZ 併用療法 + TMZ).

c ） BEV 関連の有害事象として出血, 動静脈血栓塞栓 症, 創傷治癒不全, 血栓性微小血管症, 高血圧などに注 意する。

d ） BEV による治療中は抗腫瘍効果を伴わない造影 領域や浮腫の減少 (pseudoresponse) の可能性に留意し, 非造影領域の明らかな増悪や神経所見の増悪があれば, 腫瘍の進展を考える。

\section{Anaplastic oligodendroglioma}

a ) GradeIII oligo 系腫瘍において，1p19q 共欠失のあ る腫瘍の患者は, 非共欠失に比べ, 治療法にかかわらず PFS も OS も良好である (prognostic factor).

b ） $1 \mathrm{p} 19 \mathrm{q}$ 共欠失のある gradeIII oligo 系腫瘍におい ては, 初期治療で PCV を入れることにより, PFS だけ でなくOSも有意に改善され，放射線+PCV（あるいは $\mathrm{PCV}+$ 放射線) がきわめて有効な治療法である（現時点 での標準治療).

c ） GradeIII oligo 系腫瘍において, 初期治療における
$\mathrm{PCV}$ 追加効果（生存期間延長効果）は $1 \mathrm{p} 19 \mathrm{q}$ 共欠失の有 無により予測される (predictive factor).

\section{Elderly glioblastoma}

a) 高齢者 GB に対して, TMZ 単独治療は放射線単独 治療に劣らず，治療選択肢である（ただし MGMTメチ ル化の有無を調べずして行うべきではない)。

b ） 70 歳以上の GB に対しては, TMZ 単独治療ある いは短期放射線照射 $(34 \mathrm{~Gy} / 10$ 分割あるいは $40 \mathrm{~Gy} / 15$ 分割など）が標準照射 $(60 \mathrm{~Gy} / 30$ 分割）に優る.

c ）高齢者 GB において, TMZ の効果は MGMT メチ ル化により予測され (predictive factor), メチル化の検索 は，治療方針の選択に有用である。

\section{謝 辞}

長年にわたり, 終始ご指導ご協力いただいております慶應 義塾大学医学部脳神経外科 吉田一成教授と藤田保健衛生大 学医学部脳神経外科 廣瀬雄一教授に心ょり感謝いたしま す.

\section{文 献}

1) Batchelor TT, Mulholland P, Neyns B, Nabors LB, Campone M, Wick A, Mason W, Mikkelsen T, Phuphanich S, Ashby LS, Degroot J, Gattamaneni R, Cher L, Rosenthal M, Payer F, Jürgensmeier JM, Jain RK, Sorensen AG, Xu J, Liu Q, van den Bent M: PhaseIII randomized trial comparing the efficacy of cediranib as monotherapy, and in combination with lomustine, versus lomustine alone in patients with recurrent glioblastoma. J Clin Oncol 31: 3212-3218, 2013.

2) Brandsma D, van den Bent MJ: Pseudoprogression and pseudoresponse in the treatment of gliomas. Curr Opin Neurol 22: 633-638, 2009.

3) Brem H, Piantadosi S, Burger PC, Walker M, Selker R, Vick NA, Black K, Sisti M, Brem S, Mohr G, Muller P, Morawetz R, Schold SC: Placebo-controlled trial of safety and efficacy of intraoperative controlled delivery by biodegradable polymers of chemotherapy for recurrent gliomas. The Polymer-brain Tumor Treatment Group. Lancet 345: 1008-1012, 1995.

4) Cairncross G, Berkey B, Shaw E, Jenkins R, Scheithauer B, Brachman D, Buckner J, Fink K, Souhami L, Laperierre N, Mehta M, Curran W: PhaseIII trial of chemotherapy plus radiotherapy compared with radiotherapy alone for pure and mixed anaplastic oligodendroglioma: Intergroup Radiation Therapy Oncology Group Trial 9402. J Clin Oncol 24: 2707-2714, 2006.

5) Cairncross G, Wang M, Shaw E, Jenkins R, Brachman D, Buckner J, Fink K, Souhami L, Laperriere N, Curran W, Mehta M: Phase III trial of chemoradiotherapy for anaplastic oligodendroglioma: long-term results of RTOG 9402. J Clin Oncol 31: 337-343, 2013.

6) Cairncross JG, Wang M, Jenkins RB, Shaw EG, Giannini C, Brachman DG, Buckner JC, Fink KL, Souhami L, Laperriere NJ, Huse JT, Mehta MP, Curran WJ Jr : Benefit from procarbazine, lomustine, and vincristine in oligodendroglial tumors is associated with mutation of IDH. J Clin 
Oncol 32: 783-790, 2014.

7) Chaichana KL, Zaidi H, Pendleton C, McGirt MJ, Grossman R, Weingart JD, Olivi A, Quiñones-Hinojosa A, Brem $\mathrm{H}$ : The efficacy of carmustine wafers for older patients with glioblastoma multiforme: prolonging survival. Neurol Res 33:759-764, 2011.

8) Chinot OL, Wick W, Mason W, Henriksson R, Saran F, Nishikawa R, Carpentier AF, Hoang-Xuan K, Kavan P, Cernea D, Brandes AA, Hilton M, Abrey L, Cloughesy T: Bevacizumab plus radiotherapy-temozolomide for newly diagnosed glioblastoma. $N$ Engl J Med 370:709-722, 2014.

9) Friedman HS, Prados MD, Wen PY, Mikkelsen T, Schiff D, Abrey LE, Yung WK, Paleologos N, Nicholas MK, Jensen R, Vredenburgh J, Huang J, Zheng M, Cloughesy T: Bevacizumab alone and in combination with irinotecan in recurrent glioblastoma. J Clin Oncol 27: 4733-4740, 2009.

10) Gilbert MR, Dignam JJ, Armstrong TS, Wefel JS, Blumenthal DT, Vogelbaum MA, Colman H, Chakravarti A, Pugh S, Won M, Jeraj R, Brown PD, Jaeckle KA, Schiff D, Stieber VW, Brachman DG, Werner-Wasik M, TremontLukats IW, Sulman EP, Aldape KD, Curran WJ Jr, Mehta $\mathrm{MP}$ : A randomized trial of bevacizumab for newly diagnosed glioblastoma. $N$ Engl J Med 370: 699-708, 2014.

11) Gutenberg A, Lumenta CB, Braunsdorf WE, Sabel M, Mehdorn HM, Westphal M, Giese A : The combination of carmustine wafers and temozolomide for the treatment of malignant gliomas. A comprehensive review of the rationale and clinical experience. J Neurooncol 113:163-174, 2013.

12) Herrlinger U, Schaefer N, Steinbach JP, Weyerbrock A, Hau P, Goldbrunner R, Friedrich F, Stockhammer F, Ringel F, Braun C, Kohnen R, Leutgeb B, Belka C, Urbach H, Stummer W, Glas M: Bevacizumab, irinotecan, and radiotherapy versus standard temozolomide and radiotherapy in newly diagnosed, MGMT-nonmethylated glioblastoma patients: First results from the randomized multicenter GLARIUS trial. J Clin Oncol 31 : (suppl ; abstr LBA2000) 2013.

13) Johnson BE, Mazor T, Hong C, Barnes M, Aihara K, McLean CY, Fouse SD, Yamamoto S, Ueda H, Tatsuno K, Asthana S, Jalbert LE, Nelson SJ, Bollen AW, Gustafson WC, Charron E, Weiss WA, Smirnov IV, Song JS, Olshen $\mathrm{AB}$, Cha S, Zhao Y, Moore RA, Mungall AJ, Jones SJ, Hirst M, Marra MA, Saito N, Aburatani H, Mukasa A, Berger MS, Chang SM, Taylor BS, Costello JF : Mutational analysis reveals the origin and therapy-driven evolution of recurrent glioma. Science 343: 189-193, 2014.

14) Lassman $\mathrm{AB}$, Iwamoto FM, Cloughesy $\mathrm{TF}$, Aldape $\mathrm{KD}$, Rivera AL, Eichler AF, Louis DN, Paleologos NA, Fisher BJ, Ashby LS, Cairncross JG, Roldán GB, Wen PY, Ligon KL, Schiff D, Robins HI, Rocque BG, Chamberlain MC, Mason WP, Weaver SA, Green RM, Kamar FG, Abrey LE, DeAngelis LM, Jhanwar SC, Rosenblum MK, Panageas KS : International retrospective study of over 1000 adults with anaplastic oligodendroglial tumors. Neuro Oncol 13: 649-659, 2011.

15) Lin SH, Kleinberg LR: Carmustine wafers: localized delivery of chemotherapeutic agents in CNS malignancies. Expert Rev Anticancer Ther 8: 343-359, 2008.

16) Macdonald DR, Cascino TL, Schold SC Jr, Cairncross JG : Response criteria for phase II studies of supratentorial malignant glioma. J Clin Oncol 8: 1277-1280, 1990.

17) Malmström A, Grønberg BH, Marosi C, Stupp R, Frappaz D, Schultz H, Abacioglu U, Tavelin B, Lhermitte B, Hegi ME, Rosell J, Henriksson R; Nordic Clinical Brain Tumour Study Group (NCBTSG): Temozolomide versus standard 6-week radiotherapy versus hypofractionated radiotherapy in patients older than 60 years with glioblastoma: the Nordic randomised, phase 3 trial. Lancet Oncol 13: 916-926, 2012.

18) Roa W, Brasher PM, Bauman G, Anthes M, Bruera E, Chan A, Fisher B, Fulton D, Gulavita S, Hao C, Husain S, Murtha A, Petruk K, Stewart D, Tai P, Urtasun R, Cairncross JG, Forsyth P: Abbreviated course of radiation therapy in older patients with glioblastoma multiforme: a prospective randomized clinical trial. J Clin Oncol 22: 15831588, 2004.

19) Stummer W, van den Bent MJ, Westphal M: Cytoreductive surgery of glioblastoma as the key to successful adjuvant therapies: new arguments in an old discussion. Acta Neurochir (Wien) 153: 1211-1218, 2011.

20) Stupp R, Mason WP, van den Bent MJ, Weller M, Fisher B, Taphoorn MJ, Belanger K, Brandes AA, Marosi C, Bogdahn U, Curschmann J, Janzer RC, Ludwin SK, Gorlia T, Allgeier A, Lacombe D, Cairncross JG, Eisenhauer E, Mirimanoff RO; European Organisation for Research and Treatment of Cancer Brain Tumor and Radiotherapy Groups ; National Cancer Institute of Canada Clinical Trials Group: Radiotherapy plus concomitant and adjuvant temozolomide for glioblastoma. $N$ Engl J Med 352:987996, 2005.

21) Stupp R, Hegi ME, Mason WP, van den Bent MJ, Taphoorn MJ, Janzer RC, Ludwin SK, Allgeier A, Fisher B, Belanger K, Hau P, Brandes AA, Gijtenbeek J, Marosi C, Vecht CJ, Mokhtari K, Wesseling P, Villa S, Eisenhauer E, Gorlia T, Weller M, Lacombe D, Cairncross JG, Mirimanoff RO; European Organisation for Research and Treatment of Cancer Brain Tumour and Radiation Oncology Groups ; National Cancer Institute of Canada Clinical Trials Group: Effects of radiotherapy with concomitant and adjuvant temozolomide versus radiotherapy alone on survival in glioblastoma in a randomised phase III study: 5 -year analysis of the EORTC-NCIC trial. Lancet Oncol 10: 459-466, 2009.

22) Taal W, Oosterkamp HM, Walenkamp AME, Beerepoot LV, Hanse M, Honkoop JBA, Boerman D, De Vos FYFL, Jansen RL, van den Berkmortel FWPJ, Brandsma D, Enting R, Kros J, Bromberg J, van Heuvel I, Smits M, van der Holt $\mathrm{R}$, Vernhoat $\mathrm{R}$, van der Bent $\mathrm{M}$ : A randomized phase II study of bevacizumab versus bevacizumab plus lomustine versus lomustine single agent in recurrent glioblastoma: The Dutch BELOB study. J Clin Oncol 31: (suppl; abstr 2001) 2013.

23) van den Bent MJ, Carpentier AF, Brandes AA, Sanson M, Taphoorn MJ, Bernsen HJ, Frenay M, Tijssen CC, Grisold W, Sipos L, Haaxma-Reiche H, Kros JM, van Kouwenhoven MC, Vecht CJ, Allgeier A, Lacombe D, Gorlia T: Adjuvant procarbazine, lomustine, and vincristine improves progression-free survival but not overall survival in newly diagnosed anaplastic oligodendrogliomas and oligoastrocytomas: a randomized European Organisation for Research and Treatment of Cancer phaseIII trial. J Clin Oncol 24: 2715-2722, 2006. 
24) van den Bent MJ, Brandes AA, Taphoorn MJ, Kros JM, Kouwenhoven MC, Delattre JY, Bernsen HJ, Frenay M, Tijssen CC, Grisold W, Sipos L, Enting RH, French PJ, Dinjens WN, Vecht CJ, Allgeier A, Lacombe D, Gorlia T, Hoang-Xuan K: Adjuvant procarbazine, lomustine, and vincristine chemotherapy in newly diagnosed anaplastic oligodendroglioma : long-term follow-up of EORTC brain tumor group study 26951. J Clin Oncol 31:344-350, 2013.

25) Villano JL, Wen PY, Lee EQ, Nayak L, Reardon DA, Rosenfeld MR: PCV for anaplastic oligodendrogliomas: back to the future or a step backwards? A point/counterpoint discussion. J Neurooncol 113: 143-147, 2013.

26) Wen PY, Macdonald DR, Reardon DA, Cloughesy TF, Sorensen AG, Galanis E, Degroot J, Wick W, Gilbert MR, Lassman AB, Tsien C, Mikkelsen T, Wong ET, Chamberlain MC, Stupp R, Lamborn KR, Vogelbaum MA, van den Bent MJ, Chang SM : Updated response assessment criteria for high-grade gliomas : response assessment in neuro-oncology working group. J Clin Oncol 28:1963-
1972, 2010.

27) Westphal M, Hilt DC, Bortey E, Delavault P, Olivares R, Warnke PC, Whittle IR, Jääskeläinen J, Ram Z: A phase 3 trial of local chemotherapy with biodegradable carmustine (BCNU) wafers (Gliadel wafers) in patients with primary malignant glioma. Neuro Oncol 5: 79-88, 2003.

28) Westphal M, Ram Z, Riddle V, Hilt D, Bortey E ; Executive Committee of the Gliadel Study Group: Gliadel wafer in initial surgery for malignant glioma : long-term followup of a multicenter controlled trial. Acta Neurochir (Wien) 148: 269-275, 2006.

29) Wick W, Platten M, Meisner C, Felsberg J, Tabatabai G, Simon M, Nikkhah G, Papsdorf K, Steinbach JP, Sabel M, Combs SE, Vesper J, Braun C, Meixensberger J, Ketter R, Mayer-Steinacker R, Reifenberger G, Weller M ; NOA-08 Study Group of Neuro-oncology Working Group (NOA) of German Cancer Society: Temozolomide chemotherapy alone versus radiotherapy alone for malignant astrocytoma in the elderly: the NOA-08 randomised, phase 3 trial. Lancet Oncol 13: 707-715, 2012.

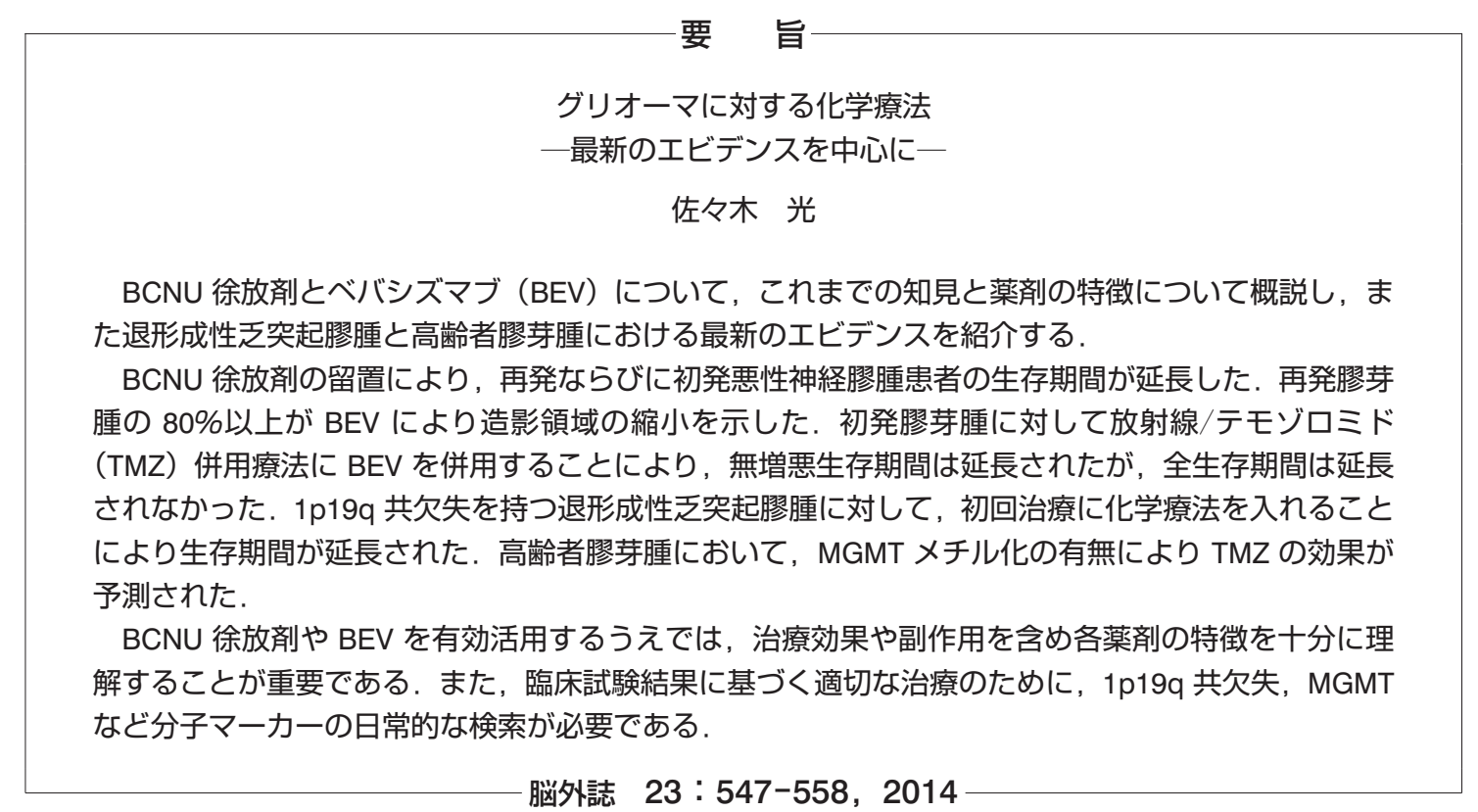

